\title{
Application on ideological and philosophical thinking of political education management for the students in colleges and universities
}

\author{
Xue-min Zhang \\ College of Political Science and Law,Heibei University,Baoding,China
}

\begin{abstract}
The characteristic of philosophy thinking and objective of higher education in China has decided the cultivation of philosophical thinking plays an important role in higher education, so higher education should not only to cultivate students into talents with specific knowledge and skills for all sorts of knowledge in the technical level,but also to pay attention to in the level of thinking in philosophy thought to influence and shape the students and in order to realize theobjective of higher education in China, to cultivate a true talent is not confined to the utilitariansense.
\end{abstract}

Keywords: philosophical thinking; ideological and political education; college students; management

\section{Introduction}

Colleges and universities as the main hub of educated youth and a variety of ideas together to collisions, is the main positions of knowledge innovation and personnel training. Since the founding of New China, all universities under the leadership of the Communist Party of China's, it has been focusing on the students' ideological and political education management,for the socialist modernization of our country to train generations of outstanding builders and successors. The 21 st century is a new century,in this century, higher education will face a big opportunity for development, the idea of college students will also presents unprecedented complexity in this openness, cultural diversity century. College students' ideological and political education in order to have a big breakthrough and greater effectiveness, we must strengthen the study of contemporary college students' ideological and political education management. Through in-depth and system analysis, a comprehensive analysis of college students' ideological and political education management status and its problems, and how to strengthen ideological and political education for exploratory research. In hopes that by studying this subject, can evoke awareness of strengthening the importance of political education management, and provide useful help on ideological and political education of college students management.

\section{Overview of the Ideological and Political Theory Education Management}

\section{1 content of ideological and political education management}

Management in all aspects of social life, and it has more than 100 years of existence of history as an independent discipline, different scholars from different angles on the management are defined, which are not discussed here. But so far, specialized research about college students' ideological and political education management is relatively small, mostly colleges and universities in the study design management to the ideological and political education and management concepts. According to the existing references, the concept of political management can be divided into the following categories, $\mathrm{Yu} \mathrm{Li}$ put on that students' ideological and political education management is to the ideological and political education work planning, 
coordination, organization and implementation by College Party and administration leaders, its purpose in students' political and moral formation, changes in the objective law of development and the task of ideological and political education for the; Wang ya-pu, who believe that the ideological and political education management is aims to reflect and apply the ideological and political education objective regular, and summaries ideological and political education management activities inherent laws, that makes the process of ideological and political education to achieve the stated objectives which the manager through some management tools; Wang xiao-xi purposed that college ideological and political management is based on the objective requirements of ideological and political work, through decision-making, planning, organizing, directing and controlling, effective use of human, financial, material, time and other information resources in order to achieve a social activity process of ideological and political work expected goals. In summary, this paper on the basis of reference [2],put that the college students' ideological and political education management refers to that in compliance with the objective laws of ideological and political education,by certain measures and means to coordinate the various relationships in ideological and political education activities, use of human, material, financial and other management resources effectively and optimize students' ideological and political education environment,which a process of achieveideological and political education goals.

\section{2 the elements of ideological and political education management}

As with all management activities, college students' ideological and political education management activities is composed of managers, management object, management mode and the results of the four basic elements:(1) the students' ideological and political education management is the management of the main body, which is composed of organization with ideological and political education management functions of students and staff members, the university student ideological and political education management relates to the school Party committee, students, the Communist Youth League and the various departments of Partygeneral branch and office of students work; (2) the student ideological education and management object is the object of management, mainly includes the student ideological and political education decision making, students' ideological and political education plan and itsimplementation, students' ideological and political education summary assessment; (3) the management mode of ideological education of students, is the means and measures of management activities of ideological and political education of the students, including a variety of administrative means, economic means and legal means, the means of education, modern management technology method and regulations; (4) the result of management of students' ideological and political education, is the ultimate goal of management activities of students' ideological and political education to achieve and to achieve the effect, the powerful condition objective is to create a good educational environment for the school and the student ideological and political education, which can ensure the realization of the aim of ideological and political education of students. Four basic factors are indispensable, otherwise can not be carried out or lose their significance.

\section{3 ideological and political education of college management}

College students' ideological and political education management activities are around the scientific decision, plan, organization and implementation, supervision and inspection,summary and evaluation of the objective of the program: (1) the initial link of the process of students' ideological and political education management is the student ideological and political education decision, before the development of students' ideological and political education work, must have individual problems, the local school or student ideological and political education in the process of determining the solution targets, and draw up theideological and political education of students in the corresponding action plan, 
the students' ideological and political education in the management process of plan, organization,examination, summary is carried out around the decision; (2) students' ideological and political education program is based on the decision objectives, its purpose is to obtain the maximum benefits with the least possible manpower, material resources, financial resources and time consumption, activity students' ideological and political education involves the organization of numerous and related personnel, covering the activities of the content is very wide and complex. In modern management, the plan is considered a "weapon" of modern management, is an important symbol of scientific management, so the school all the relevant departments must develop a plan of ideological and political education in time, realizing the maximization of the student ideological and political education effect; (3) organization and implementation of the basic means to achieve management goals, which is the main ideological and political education management organization with the necessary human, material, financial and other management resources to students' ideological and political education plan were implemented, so that management objectives are achieved; (4) the supervision and inspection is for decision-making, planning, implementation and achieve the goal of influencing a means, it plays a very important role in the process of management, including the comprehensive supervision and verification of decision and plan foresight, track inspection and guidance to implementation and supervision, the management system of each member in the examination and supervision; (5) summary assessment is college students 'ideological and political education of the end part of the management process, it uses the scientific method has been done to assess the students' ideological and political education, affirming the achievements, identify gaps, lessons learned, lessons learned. These five aspects are interrelated and mutually reinforcing mutual restraint, the overall configuration management process of ideological and political education of college students.

\section{Analysis of Contemporary College Students' Ideological and Political Education Management Problems}

In recent years, because of the national and university students attach importance toideological and political education, ideological and political education of college studentsmanagement work has made gratifying achievements, as follows: (1) reform of ideological and political education management system and the construction of college students have achieved some initial success; (2) universities basically established schools, the family and the social three aspects to catch condominium management system; (3) the construction of the ranks of ideological and political education of students, especially the improvement of the quality of the team has been further attention; (4) there was a further development of management method, various universities and gradually improve the students' ideological and political education evaluation system. Although the university student ideological and political education management have made great achievements, in order to achieve the management of ideological political education of university students of sciencehigh, still has the very big promotion space, the main show as follows: construction management system is not perfect, lack of the necessary management system internal communication and coordination, management method is relatively simple, management assessment to some extent formality.

\section{Application of Philosophical Thinking in Ideological and Political Education of College Students}

Philosophy is the reflection of a nation's highest level of abstract thinking, the thinking ability is theory of human performance and product, in essence is a kind of theoretical thinking, which is different from the specific scientific thinking. Philosophical thinking of the whole world is the most general essence and the universal law as its reflection object, infinite thinking is a truthand value of unity, is a kind of transcendence of time and 
experience speculative activity, with uncertainty and generality, more abstract than scientific thinking, more general. Philosophical thinking is transcendent, ideal, critical. The higher education of our country has walked up to today, the social development demand of knowledge so that we can't emphasize higher education social significance, combined with social and university became the new characteristics of higher education. However, too much emphasis on the social value of education, although can solve many problems in daily life, it also brings some negative effects,such as neglect theory value, practical knowledge and skills; the cultivation of philosophical thinking lax; satisfied with ready-made, can see the effectiveness of learning. In fact, the theoretical construction and analysis is essential for higher education, ignoring the cultivation of students' philosophy, higher education will depreciate the real value.

To give full play to the important role of philosophy and Social Science in the development of economy and society, the realization of Social Science in modern society, especially in the higher education in the role, to improve the philosophical thinking ability and level of highertalents. It is based on this reality and hope for the future, we should emphasize the role of philosophy thinking in higher education, forming a serious search thinking teaching and learning atmosphere, realized in the Chinese college students' ideological and political education management in philosophical thinking level leap.

\section{Suggestions on Strengtheningthe Ideological and Political Education of College Students Management}

\section{1 strengthening the effectiveness of management} awareness and behavior

College students' ideological and political education is a systematic project, which is the operator and the management of the main actors in this system works. Management body determines the degree of consciousness and behavior can achieve the effect of management activities.A dominant role,behavior management awareness of managementmain body and therefore,to form the correct consciousness of management, which is conducive to the management of the main management functions into full play the role ofprompting management work effect. students train to become the all-round development of morality, intelligence and physique of the students an important guarantee, is to ensure that the consolidation of political stability and unity, lively and the development important force. Under the condition of importance in improving management awareness, management must also be done on the subject of ideological and political education of students and scientific management. Only through scientific management, in order to put as little as possible to obtain the greatest benefits.

\section{2 strengthen management innovation of Ideological and Political Education}

To really establish a new system, the management of college students ideological and political education must first to reform the original, organize and implement the unified leadership of the party committee of student ideological and political education management system. The key to the reform of this system is that principals, Party committees should change idea,improve knowledge, actively set up the ideological and political education managementconsciousness of students, like attention to teaching, research attention to the students'Ideological and political education, to ensure the correct direction of ideological and political education of the students.

\section{3 the innovation of the ideological and political education environment}

Existence determines consciousness, the spirit of the decision of material. Time has proved thatthe campus culture activities helps students to establish a correct world values, aims to cultivate their sentiments, beautify 
their personality, regulate their behavior. The environment of Ideological and political education in Colleges and universities is mainly refers to the university culture, including material cultureand spiritual culture environment in two aspects of the environment.

\section{Conclusions}

No matter from the social practice of ideological and political education are facing external requirements of ideological and political education theory system itself or from the internal logic of development view, the ideological and political education in the further development of the times, we need a keen philosophical perspective and philosophical thinking support, but also need proof of philosophy. Meanwhile, philosophy in ideological and political education embodies the spirit of the times,demonstrated the wisdom of philosophy, the two intersection and symbiosis, it has been an inevitable trend of development.

\section{References}

[1] LV hong-yu.The development trends of ideological and political education and its philosophy needs[J].Journal of baicheng normal college,pp5-8,2009(10).

[2] Mo yun-yun.The research of ideological political education administration for the students in colleges and universities in the new century[D].Tianjin University,2007. [3]Yao dong. The significance of cultivating philosophical thinking of students for higher education[J].Joural of lianyugang teachers college,pp66-68.2004.

[4]Gong wen. The theory of ideological and political education value realization of college[D]. Shandong normal university, pp23-34, 2011 